\title{
Szédülés vizsgálata \\ a sürgősségi osztályon: új, ágy melletti diagnosztikai eljárások
}

\author{
Tamás T. László dr. ${ }^{1}$. Garai Tibor dr. ${ }^{1}$, \\ Tompos Tamás dr. ${ }^{1}$ - Szirmai Ágnes dr. ${ }^{2}$
}

\author{
${ }^{1}$ Petz Aladár Megyei Oktató Kórház, Fül-Orr-Gégészeti és Fej-, Nyaksebészeti Osztály, Győr \\ ${ }^{2}$ Semmelweis Egyetem, Általános Orvostudományi Kar, Fül-Orr-Gégészeti és Fej-Nyaksebészeti Klinika, Budapest
}

A nemzetközi statisztikai adatok szerint a szédülő betegek 25\%-ának első vizsgálata a sürgősségi osztályon történik. A vizsgáló orvos legfontosabb feladata, hogy diagnosztizálja az életet veszélyeztető kórfolyamatokat. Ezek közül az egyik legnehezebb az izolált szédülés tüneteivel jelentkező veszélyes hátsó scala területi stroke és a jóindulatú vestibularis neuritis elkülönítése. Az utóbbi években bevezetett, gyors, noninvazív, bizonyítékon alapuló, ágy melletti vizsgálatok segítségével a két kórkép teljes biztonsággal differenciál diagnosztizálható. A jóindulatú neuritis vestibularist utánzó stroke (pseudoneuritis) 35\%-át tévesen diagnosztizálják, és az ilyen esetek 40\%-a után szövődmény alakul ki. Az oculomotoros rendszer kóros múködésén alapuló új, gyors, ágy melletti tesztek szenzitivitása az első 48 órában stroke vonatkozásában jobb, mint a diffúziósúlyozott koponya mágneses magrezonanciás vizsgálaté. Egy speciális vizsgáló szemüveg segítségével az új teszt minden komponense objektivizálható, reprodukálható. Orv. Hetil., 2016, 157(11), 403-409.

Kulcsszavak: ágy melletti diagnosztika, akut vestibularis szindróma, bizonyítékon alapuló, sürgősségi betegellátás, szédülés

\section{Vertigo in the Emergency Department: new bedside tests}

According to international statistics, the first examination of $25 \%$ of patients with vertigo is carried out in Emergency Departments. The most important task of the examining physician is to diagnose life threatening pathologic processes. One of the most difficult otoneurological diagnostic challange in Emergency Departments is to differentiate between dangerous posterior scale stroke presenting with isolated vertigo and the benign vestibular neuritis. These two disorders can be safely differentiated using fast, non-invasive, evidence based bedside tests which have been introduced in the past few years. 35\% of stroke cases mimicking vestibular neuritis (pseudoneuritis) are misdiagnosed at the Emergency Department, and $40 \%$ of these cases develop complications. During the first 48 hours, sensitivity for stroke of the new test that is based on the malfunction of the oculomotor system is better than the diffusionweighted cranial magnetic resonance imaging. Using special test glasses each component of the new test can be made objective and repeatable.

Keywords: acute vestibular syndrome, bedside test, emergency, evidence based, vertigo

Tamás, T. L., Garai, T., Tompos, T., Szirmai, Á. [Vertigo in the Emergency Department: new bedside tests]. Orv. Hetil., 2016, 157(11), 403-409.

(Beérkezett: 2016. január 6.; elfogadva: 2016. január 28.)

\section{Rövidítések}

ABCD2 = (Age, Blood pressure, Clinical features, Duration of symptoms, Diabetes) kor, vérnyomás, klinikum, tünetek fennállásának időtartama, diabetes; AICA = arteria cerebelli inferior anterior; AVS = akut vestibularis szindróma; $\mathrm{BPPV}=$ benignus paroxysmalis pozicionális vertigo; CT = komputertomográfia; EKG = elektrokardiográfia; GCS = Glasgow Kóma Skála; HINTS $=$ (Head Impulse test, direction-changing Nystagmus, Test of Skew deviation) fejimpulzusteszt, irányváltó nystagmus, skew deviáció vizsgálata; INFARCT $=($ Impulse Normal, 
Fast-phase Alternating, Refixation on Cover Test) normális fejimpulzusteszt, váltakozó gyors fázis, refixáció a cover teszten; LED = light emitting diode; MRI = mágneses rezonanciás képalkotás; PICA = arteria cerebelli inferior posterior; $\mathrm{SBO}=$ sürgősségi betegellátó osztály; SCA = arteria cerebelli superior; $\mathrm{SM}=$ sclerosis multiplex; TIA = tranziens ischaemiás attak; VOR $=$ vestibuloocularis reflexív

A szédülés a különböző lokalizációjú fájdalmak mellett az egyik leggyakoribb, sokszor ijesztő tünet, amely a beteget az orvoshoz viszi. A teljes lakosság $42 \%$-a élete folyamán legalább egyszer szédülés, egyensúlyzavar miatt orvoshoz fordul [1]. Mivel határterületi problémáról van szó, a beteg jelentkezhet háziorvosánál, fül-orr-gégészeti és neurológiai szakrendelésen egyaránt. A beteg érkezhet krónikus panaszokkal a saját lábán és előfordulhat, hogy rossz, szinte vizsgálhatatlan állapotban a mentő szállítja a sürgősségi betegellátó osztályra $(\mathrm{SBO})$. Hazánkban egy felmérés szerint a betegek 3\%-a érkezik elsődlegesen szédüléses panaszok miatt az SBO-ra, azonban a célzott anamnézisfelvétel során a sürgősségi betegek több mint $50 \%$-a számol be az észlelést megelőző 7 napban tapasztalt szédülésről $[2,3]$. Pontos magyarországi adatok hiányában amerikai szerzők munkáira hivatkozunk, amely szerint az összes szédülő beteg 25\%-a jelentkezik az SBO-n [4]. A szédüléssel járó betegségek nemzetgazdasági hatásáról Magyarországon nem készült felmérés, de az Amerikai Egyesült Államok adatai szerint az ilyen panaszokkal jelentkező betegek $26 \%$-a válik tartósan munkaképtelenné, ez a tény 2,25 billió dollár kiesést jelent a költségvetésból [5]. Valószínúleg - arányosan - a mi hazai adataink sem jobbak ennél. Ebbőll a szempontból is fontos tehát, hogy a beteg minél elóbb definitív diagnózishoz és kezeléshez jusson. A szédülés hátterének gyors tisztázása és adekvát ellátása a sürgősségi feladatokat ellátó osztályok számára problémákat vethet fel, miután az akut ellátás során az észlelő orvos általában nem specialista. A probléma jelentőségét jelzi, hogy a felmérések szerint az SBO-on dolgozó orvosok klinikai prioritási sorrendjében a második helyen áll a súlyos szédüléses panaszok diagnosztikája, és a kollégák keresik a diagnosztikus vezérfonalakat [6]. Alapvető, hogy meghatározzuk a diagnosztika feladatait, amelyek kettősek: elsődleges célunk, hogy kiszürjük a potenciálisan életet veszélyeztető kórképeket, másrészt minél előbb fel kell állítanunk egy definitív diagnózist. Az utóbbi cél teljesülése esetén nagy eséllyel csökkenteni tudjuk a felesleges vizsgálatok elvégzését, a szükségtelen iatrogén ártalmakat és meggátolhatjuk az organikus elváltozásokra ráépülő szorongásos betegség és szubjektív krónikus szédülés kialakulását [7]. E célok elérésére magyar szerzők már korábban is erőfeszítéseket tettek, amelyek közül elsősorban orvostörténeti jelentőséggel bír, hogy 1907-ben Politzer Ádám, a Nobel-díjas Bárány Róbert dolgozatának előszavában a munkát a fül-orr-gégészek, neurológusok mellett a traumatológusok (mai olvasatban akár sürgősségi orvosok) számára ajánlotta

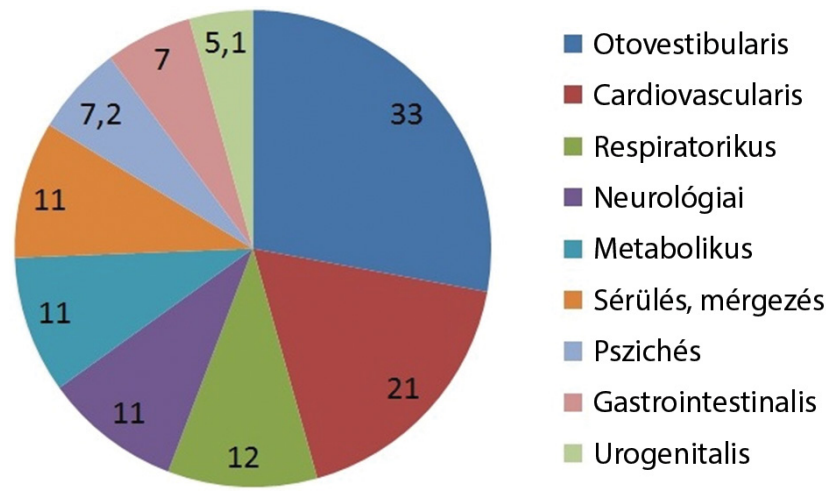

1. ábra $\quad$ A sürgősségi ellátást igénylő vertigo/dizziness okai (amerikai adatok alapján) az összes eset százalékában

[8]. 2011-ben Szirmai a részletes otoneurológiai vizsgálatra szoruló betegek előzetes kiválasztására 6 pontból álló kérdőívet javasolt [9]. Varga és mtsai-2014-ben a sürgősségi osztályon elvégzett vizsgálatukban - a szédülés diagnózisának felállításához leghasznosabbnak a részletes anamnézisfelvételt és a célzott neurológiai vizsgálat elvégzését tartották, és megállapították, hogy - hasonlóan Newman-Toker adataihoz - az összes beteg közel 3\%-a érkezett szédüléses panaszokkal [2-4]. Büki 2014ben könyvfejezetben foglalta össze a sürgősségi osztályon előforduló szédülések diagnosztikai feladatait és bizonyítékon alapuló új, ágy melletti vizsgálómódszereit [10].

\section{A szédülések etiológiája az SBO-n}

Ha megvizsgáljuk a sürgősségi ellátást igénylő szédülések okait az Amerikai Egyesült Államokban, akkor szembeötlő, hogy az etiológia rendkívül sokrétú, de az esetek csaknem harmada perifériás eredetú, és gyakoriságban 2. helyen a cardiovascularis történések állnak. A 4\%-os arányt reprezentáló cerebrovascularis okok potenciálisan urgens, életet veszélyeztető kórképeket jeleznek (agytörzsi, illetve cerebellaris stroke-ot). A sürgősségi ellátást igénylő vertigo/dizziness okait (amerikai adatok alapján) az összes eset százalékában az 1. ábrán mutatjuk be.

A magyarországi adatok alapján, ahol a retrospektív adatfeldolgozást követően a szédülés okait a BNO-kódoknak megfelelően osztályozták, $56,7 \%$-ban a szédülékenység volt a vezető BNO-kód. Ezt követte sorrendben az egyensúlyzavarok (11,9\%), a központi eredetû́ szédülés $(9,3 \%)$, a benignus paroxysmalis pozicionális vertigo (BPPV) $(8,5 \%)$, majd az egyéb perifériás eredetû szédülés $(7,4 \%)$, illetve az egyéb szédülések kategória $(6,2 \%)$. A szédülés hátterében nem született specifikus diagnózis az esetek $57 \%$-ában [2].

\section{A szédülések csoportosítása az SBO-n}

A szédülés kimenetele szempontjából beszélhetünk veszélyes és jóindulatú szédülésről; a rohamok ismétlődése 
szerint megkülönböztetünk első vagy visszatérô szédüléses rohamokat; az időtartam szerint tranzicionális vagy tartós; végül a kísérő tünetek jellege szerint izolált vagy kombinált típusú szédülést.

Newman-Toker vizsgálatai szerint a leggyakoribb jóindulatú okok a következők voltak: az összes vizit 6,6\%ában vasovagalis syncope, $5,6 \%$-ban vestibularis neuritis, 1,1\%-ban migrén, 0,7\%-ban BPPV, 0,6\%-ban orthostaticus hypotonia, 0,3\%-ban Ménière-betegség. A veszélyes okok között a leggyakoribbak a folyadékháztartás zavarai voltak $(5,6 \%)$, amelyeket a kardiális aritmia $(3,2 \%)$, tranziens ischaemiás attak (TIA) $(1,7 \%)$, anaemia $(1,6 \%)$, hypoglykaemia $(1,4 \%)$, angina $(0,9 \%)$, myocardialis infarctus $(0,8 \%)$ és stroke/intracerebralis vérzés $(0,5 \%)$ követett [4]. Azokat a szédüléses rohamokat, amelyek rövidek és önmaguktól megszûnnek, tranzicionális szédüléseknek nevezzük. A panaszok megszűnésének ellenére itt is fontos felállítanunk egy diagnózist, mivel potenciálisan veszélyes okok állhatnak a háttérben. Problémát jelenthet az is, hogy a vizsgálat időpontjában még nem tudhatjuk, hogy a szédülés mennyi ideig fog tartani. A folyadék- és az elektrolit-háztartás zavarain kívül $(5,6 \%)$, a kardiális aritmia $(3,2 \%)$ és a hátsó scalai keringési zavar okozta TIA $(1,7 \%)$ a leggyakrabban észlelt tranzicionális jellegü szédülés az SBO-n. Az új adatok szerint a stroke gyakran az első TIA-panaszok jelentkezése után hamarosan felléphet. Fontos a korai diagnózis (amelybe beletartozik a kardiogén emboliaforrások kutatása) és a stroke-megelőző kezelés. Az átmeneti szédülést okozó jóindulatú, perifériás jellegű kórképek közül a $\operatorname{BPPV}(0,6 \%)$ és a Ménière-betegség $(0,3 \%)$ a leggyakoribb [4].

$\mathrm{Az}$ elhúzódó, 24 órán túl tartó szédülésrohamokat akut vestibularis szindrómának (AVS) nevezzük. Tarnutzer és mtsai definiálták az AVS fogalmát: Olyan akut, émelygéssel és hányással, egyensúlyzavarral, nystagmusszal és fejmozgási intoleranciával kísért, 24 órán túl tartó szédülés, amelyet leggyakrabban vestibularis neuritis vagy agytörzsi, illetve kisagyi stroke okoz [11]. Ez a kritérium kizárja a legtöbb olyan átmeneti jellegű szédülést, amely másodpercekig-percekig vagy órákig tart, mint a BPPV, kardiális aritmia, TIA. Kivétel lehet a Ménière-betegség és a vestibularis migrén, ahol 12\%ban, illetve 27\%-ban a szédülések I napnál tovább tarthatnak $[12,13]$. Az AVS-ben a leggyakoribb perifériás ok a vestibularis neuritis. A centrális okok közül leggyakoribb a hátsó scalai stroke (79\%), ezt követi a sclerosis multiplex (SM) (11\%) és a vérzés (4\%) [10]. Az AVS gyakran előforduló okait az 1. táblázatban, a ritkábban előforduló kórképeket a 2. táblázatban foglaltuk össze.

A statisztikák szerint az SBO-n a szédülő betegek 1020\%-a jelentkezik AVS tüneteivel [4]. A kórképek 75\%-a perifériás, vestibularis neuritis vagy labyrinthitis, 25\%-uk pedig centrális (ezek $80 \%$-a hátsó scala területi stroke, többnyire ischaemiás). A stroke-esetek $25 \%$-a 50 év alatti! Ez az adat különösen aláhúzza annak a téves koncepciónak a jelentőségét, amely szerint fiatal életkorú beteg-
1. táblázat | A AVS leggyakoribb okai [4]

\begin{tabular}{l} 
Jóindulatú, kevésbé sürgős okok \\
\hline Vestibularis neuritis \\
Sclerosis multiplex \\
\hline Veszélyes, sürgős okok \\
\hline Agytörzsi vagy cerebellaris infarktus \\
Agytörzsi vagy cerebellaris vérzés
\end{tabular}

2. táblázat |Az AVS ritkán (1\%-nál kevesebbszer) előforduló okai [4]

Jóindulatú, kevésbé sürgős okok

Vírusos labyrinthitis

Ramsay-Hunt-szindróma

Akut traumás vestibulopathia

Vestibulotoxicitas

Akut encephalomyelitis

Központi idegrendszerre ható gyógyszerek mellékhatása

Elhúzódó Ménière-roham

Elhúzódó vestibularis migrénroham

Epizodikus ataxiaszindróma rohama

Otosyphilis

Lyme-kór

Degeneratív cerebellaris ataxia

Kisagy-hídszögleti daganat

\section{Veszélyes, sürgös okok}

Labyrinthstroke

Bakteriális labyrinthitis

Mastoiditis

Wernicke-szindróma

Miller-Fisher-szindróma

Agytörzsi encephalitis

Paraneoplasiás eredet

nél a szédülés hátterében nem állhat fenn stroke. Az AVS hátterében az esetek 80\%-ában nem tudunk kimutatni neurológiai gócjelet, ezeket a kórképeket izolált AVSnek nevezzük. Az AVS $25 \pm$ 15\%-a stroke következménye, és az ilyen esetek 50\%-ában hiányoznak a neurológai gócjelek [11]. Ezen utóbbi eseteket nehéz lehet megkülönböztetni az AVS-t okozó leggyakoribb jóindulatú betegségtől, a vestibularis neuritistől. Ez a feltételezetten vírusos eredetû, spontán gyógyuló entitás jóval gyakoribb, mint centrális hasonmása, a cerebellaris vagy agytörzsi stroke okozta pseudoneuritis. A kettő közötti differenciáldiagnózis fontos, mivel akiknél az akut vestibularis tünettan centrális eredetű, azoknál ismételt stroke-ra lehet számítani, továbbá a stroke szoros moni- 
torizálás nélkül fatális is lehet [14]. A páciensek 10-20\%ánál, akár az SBO-ról történő elbocsátást követően, a cerebellaris stroke által okozott agytörzsi kompresszió és hydrocephalus miatt állapotromlás következik be a stroke-ot követő napokban, és a legnagyobb fokú agyödéma a 3. napon jelentkezik [15]. Figyelmeztető adatokat közölt Newman-Toker: az Amerikai Egyesült Államok sürgősségi osztályain a pseudoneuritisek 35\%-át tévesen diagnosztizálják (50-70 000/év) [16]. Ez az adat különösen akkor szembetûnő, ha összehasonlítjuk azzal a 4\%-os téves diagnosztikai aránnyal, amikor neurológiai góctünetek is fennállnak. A legfontosabb neurológiai góctüneteket az angol szakirodalom „deadly D's” ( "halálos D-k”) kifejezéssel illeti: diplopia, dysarthria, dysphagia, dysphonia, dysmetria, dysaesthesia, drop attak. Ezeket a tüneteket célirányosan kell keresnünk. A cikkírók következő észrevétele az volt, hogy a tévesen diagnosztizált betegek 40\%-ánál szövődmény jelentkezik (15-30 000/év), és a szövődmények aránytalanul az 50 év alatti korosztályt érintik. 18-44 év között 7-szer gyakoribb a téves diagnózis, mint a 75 év feletti korosztályban. Savitz tévesen diagnosztizált cerebellaris infarktusos esetekről közölt összefoglaló cikket. A kezdeti diagnózis 15 fiatal páciens esetén migrén, toxikus encephalopathia, gastritis, meningitis, myocardialis infarctus és polineuropathia volt. A mortalitás magas volt (40\%), és a túlélők felében rokkantságot okozó károsodások alakultak ki [17]. A téves diagnózis a fiatalok mellett a leggyakoribb a nők és a kisebbségiek esetében volt (20-30\%) [14]. Tarnutzer vizsgálatai szerint a fiataloknál nemcsak a stroke-ot, hanem a szintén életet veszélyeztető arteria vertebralis dissectiót is gyakran tévesen diagnosztizálják. Az utóbbit könnyen összetévesztik a vestibularis migrénnel [11]. Newman-Toker és munkacsoportja megállapította továbbá, hogy az SBO-n BPPV, illetve neuritis vestibularis tüneteivel jelentkező pácienseket ugyanolyan gyakran küldik képalkotó vizsgálatokra, mint a többi szédülés esetén. További észrevételük volt, hogy az SBO-s orvosok 11\%-a végzi csak el a pozicionális vizsgálatokat (BPPV) és csak 5\%-uk dokumentálja, valamint, hogy a dokumentált nystagmus iránya összeegyeztethetetlen a BPPV vagy a vestibularis neuritis diagnózisával az esetek 81\%-ában (113/140). A perifériás jellegű szédülések első diagnózisa 59\%-ban (19/32) volt téves, és 67\%-ban (15/26) a centrális okot is rosszul diagnosztizálták [18]. Az orvosi gondolkodásban a legtöbb félreértésre az okot az adta, hogy úgy vélték, hogy negatív neurológiai státusz melletti vertigo nem lehet stroke, illetve a negatív koponya-CT és a negatív koponya-MRI biztosan kizárja a stroke-ot. A rutin-koponya-CT-vizsgálatoknak alacsony a szenzitivitása az akut ischaemiás cerebellaris stroke esetén, mivel a hátsó scalában a csont nagyon vastag és a mútermékek miatt nehezen ábrázolható az ischaemiás laesio. Hwang és mtsai a koponya-CT szenzitivitását $42 \%$-osnak találták 30 órán belül elvégezve a vizsgálatot [19]. A vizsgálóknak tudatában kellene lenni az MRI korlátainak is. Stroke esetén 48 órán belül elvég- zett öt diffúziósúlyozott koponya-MR-vizsgálatból egy fals negatív eredményt ad [10]! További diagnosztikai tévedésre lehetőséget adó sztereotípia, hogy a halláscsökkenés veszélytelen szédüléssel jár. Azonban AICAinfarktus esetén a stroke érintheti a belső fület és a vestibularis magvakat is, ezáltal kombinált centrális és perifériás vestibularis károsodást okozhat, perifériás jellegü jóindulatú szédülést utánozva [20]. Nemcsak a hirtelen halláscsökkenés lehet figyelmeztető jele a stroke-nak, hanem a hirtelen, váratlan kezdet [21], a hirtelen, intenzív, folyamatos craniocervicalis fájdalom [13] és a különböző tünetek közötti aránytalanság (extrém törzsataxia, illetve folyamatos hányás, alig észrevehető nystagmus mellett) is [22]. Az anamnézisben hetek, hónapok óta hátsó scala területi TIA-ra típusos visszatérő szédülések 29\%-ban fennállnak [11].

\section{A szédülő betegek vizsgálatának menete az SBO-n}

Úgy tünik, hogy a Drachman által leírt felosztásnak megfelelő szédüléses panaszok kvalitása alapján (vertigo, dizziness, praesyncope, light headedness) nem tudjuk differenciálni a veszélyes és a jóindulatú szédüléseket [23]. Egyrészről azért, mert a páciensek nem pontosan írják le a panaszaikat, az SBO-n akár 10 percen belül megváltoztatják véleményüket a szédülés kvalitásairól, amikor másodszor is kérdezzük őket. Másrészt pedig azért, mert bármilyen pontosan írják is le a panaszaikat, a fenti négy kategória átfed veszélyes kórképeket is [24]. Cardiovascularis betegség is sokkal gyakrabban okoz forgó jellegű szédülést, mint azt korábban gondoltuk. A szédüléssel jelentkező cardiovascularis páciensek metaanalízise során azt találták, hogy 63\%-nál a vertigo mellett egyéb tüneteik is jelentkeztek, azonban 37\%-uknak a forgó jellegú szédülés volt az egyetlen tünete [25]. A sürgősségi osztályon a betegek ellátása során a vitális paraméterek ellenőrzése (légzés, keringés, RR, $\mathrm{SpO}_{2}$, hőmérséklet), a tudatállapot rögzítése (Glasgow Kóma Skála - GCS), EKG- és laboratóriumi vizsgálatok (ionháztartás, vérkép) elvégzése mellett a legfontosabb teendő a részletes anamnézisfelvétel, amelyben célirányos kérdések lehetnek a segítségünkre: Mennyi ideje tart a szédülés? Első vagy ismétlődő roham? Provokálja-e ...? Kíséri-e ...? Megelőzte-e ...? Szenved-e egyéb betegségekben?

Az anamnézisfelvételt követő, ágy mellett elvégzendő vizsgálatokat a 3. táblázatban foglaltuk össze.

A nystagmus vizsgálata során a fixáció kikapcsolása alapvető fontosságú. Az otoneurológus Frenzel-szemüveg nélkül olyan, mint a belgyógyász fonendoszkóp nélkül! Szükség esetén a beteg szeme elé tartott fehér lap vagy a szemébe világító light emitting diode (LED) fény segítségével is kikapcsolható a fixáció az SBO-n. Fontos gyanújel a stroke-ra, ha a beteg egyedül nem tud megállni, illetve járni, ezért lehetőség szerint az önálló állás képességét vizsgálnunk kell [26]. Az utóbbi években az 
3. táblázat |Ágy melletti vizsgálatok az SBO-n [10]

\begin{tabular}{l}
\hline 1. Nystagmus keresése \\
\hline Spontán nystagmus van: \\
- fixációval \\
- fixáció nélkül (Frenzel- vagy Bartels-szemüveg!) \\
- tekintésirányú nystagmus \\
\hline 2. Cover-teszt, ocular tilt vizsgálata
\end{tabular}

3. Provokációs tesztek

Spontán nystagmus nincs:

- fejrázási teszt

- pozicionális tesztek

4. VOR-teszt (Halmágyi-Curthoys-teszt)

5. Neurológiai gócjelek keresése

6. Fülészeti vizsgálat (otoszkópia, súgott beszéd vizsgálat)

AVS differenciáldiagnosztikájára új, magas specificitású és szenzitivitású, ágy melletti teszteket fejlesztettek ki, amelyek még az első órákban is segítenek, amikor a neuroradiológiai diagnosztika nem megbízható vagy nem elérhető [27]. A vizsgálatok érzékenységének az alapja az, hogy a stroke után a fiziológiás szemmozgások azonnal megváltoznak, a struktúra (MRI) pedig csak később. Ezek közül a tesztek közül kiemelkedő jelentőségű a fejimpulzusteszt, szerzői nevén a Halmágyi-Curthoysteszt, amely Brandt szerint a szédülés legfontosabb, ágy melletti diagnosztikai vizsgálata $[28,29]$. Az AVS leggyakoribb kórokában, a vestibularis neuritisben károsodott a VOR, ezért a páciens a horizontális ívjáratok síkjában elvégzett kis amplitúdójú, nagy sebességü, passzív, a károsodott oldal felé történő fejfordítás során nem tud fixálni egy adott pontot. A szem a fejjel együtt elfordul és egy jól látható, az egészséges oldal felé irányuló kompenzatorikus saccáddal ugrik vissza a fixált pontra. Mivel az arteria cerebelli inferior posterior (PICA) és az arteria cerebelli superior (SCA) infarktus esetén a vestibuloocularis reflexív (VOR) intakt marad, a Halmágyi-Curthoysteszt egy gyors és könnyű differenciáldiagnosztikai lehetőséget biztosít a vestibularis neuritis és a PICA, valamint az SCA-területi stroke között. Amennyiben a teszt mindkét irányban negatív (azaz ebben az esetben a VOR nem károsodott), akkor az adott AVS hátterében stroke gyanúja merül fel. Azonban a pozitív fejimpulzusteszt a vizsgálót hamis biztonságérzetbe ringathatja például az arteria cerebelli inferior anterior (AICA) infarktus esetén, amely ugyan 5-ször ritkább a PICA-területi strokenál, azonban ilyenkor a károsodás érintheti a belső fület és a vestibularis magvakat is, ezáltal kombinált perifériás és centrális vestibularis károsodást okozhat [21]. Ebben az esetben a potenciálisan veszélyes cerebellaris stroke ellenére a fejimpulzusteszt lehet pozitív. Ezért további centrális oculomotoros eltéréseket kell keresnünk. Mivel az AICA-területi stroke gyakran jár együtt centrális szemmozgási zavarokkal, a betegeknek vagy tekintésirányú nystagmusa van, vagy a centrális otolitpályák károsodása miatt kialakul egy vertikális skew deviáció. Ezért Kattah és mtsai javasolták egy 3 lépésból álló, ágy melletti teszt alkalmazását, amely a Head Impulse (fejimpulzus-) tesztből, a tekintésirányú Nystagmus és a Test of Skew deviáció célzott kereséséból áll (HINTS) [27]. A stroke lehetőségét jelző vizsgálati eredmények alapján a szerzők javasoltak egy második mozaikszót is: Impulse Normal, Fast-phase Alternating vagy Refixation on Cover Test (INFARCT) [27]. Egy metaanalízis kimutatta, hogy az összetett HINTS-vizsgálat szenzitivitása 100\% és specificitása $96 \%$ a stroke-ra, és AVS esetén ez az eredmény jobb, mint a diffúziósúlyozott MRI találati aránya az első 24 és 48 órán belül. A 96\%-os specificitás azt jelzi, hogy ritkán álpozitív esetek előfordulhatnak. Rövid ideig (1-2 nap) vestibularis neuritis esetén is elöfordulhat skew deviáció [30]. Vestibularis neuritisben azonban az ipsilateralis akut halláscsökkenés hiányzik, ezért a HINTS-vizsgálat kiegészítése a betegágy melletti fül- és hallásvizsgálattal (otoszkópia, hangvilla és súgott beszéd vizsgálat, HINTS plusz [plusz = hirtelen keletkezett halláscsökkenés]) a specificitást 99\%-ra emeli. A HINTS plusz vizsgálat hatékonysága nemcsak a 48 órán belül elvégzett diffúziósúlyozott koponya-MRI, hanem a hagyományos, Age, Blood pressure, Clinical features, Duration of symptoms, Diabetes (ABCD2) rizikófaktorok jelenlétén alapuló vizsgálatok hatékonyságán is túltesz a stroke vonatkozásában [31]. A diagnosztikus döntést segítő, vestibularis neuritis okozta AVS-re utal a következő mozaikmondat: SEND HIM ON HOME, amely az alábbi vizsgálati eredmények angol nyelvú kezdőbetúiből áll össze: Straight Eyes, No Deafness, Head Impulse Misses, One-way Nystagmus, Healthy Otic and

\begin{tabular}{l|l} 
4. táblázat & $\begin{array}{l}\text { Az izolált szédülést okozó agytörzsi vagy cerebellaris stroke és } \\
\text { a vestibularis neuronitis differenciáldiagnózisát segító táblázat }\end{array}$
\end{tabular}

\section{INFARCT}

Impulzus Normális

Fázis Alternáló

Refixáció a Cover Teszten

\section{NE PISZMOGJ!}

Nystagmus Egyirányú

Pozitív Impulzus

Szimmetrikus (hallás)

Mastoid Ok

Golyó (szem) Jó 
Mastoid Exemination. A szerzók kísérletet tettek az INFARCT mozaikszó és a SEND HIM ON HOME mozaikmondat magyar megfelelőjének a megalkotására, amely könnyen megjegyezhető, az AVS differenciáldiagnózisát segítő vizsgálati leleteket sorolja fel és összhangban áll az eredeti angol kifejezések jelentésével (4. táblázat).

Az utóbbi években lehetôségünk adódik a HINTS regisztrációjára, a Halmágyi-Curthoys-teszt, a tekintésirányú nystagmus és a vertikális skew deviáció objektív vizsgálatára alkalmas speciális szemüveg segítségével [32, 33] (2. ábra).

\section{Következtetések}

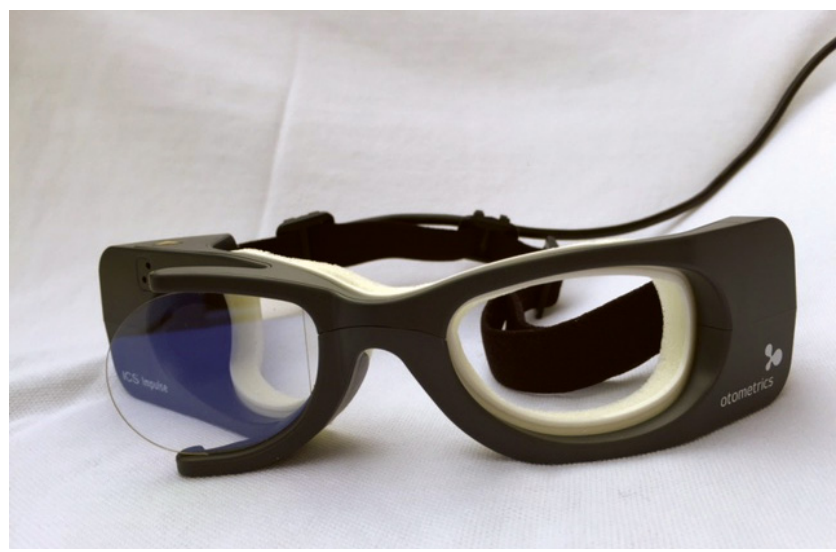

2. ábra

A HINTS-teszt objektív vizsgálatára alkalmas videoregisztrált fejimpulzusteszt-szemüveg

Az SBO-ra érkező, akut szédüléssel jelentkező betegek panaszai mögött az esetek többségében jóindulatú okok állnak. Néhány páciens azonban súlyos, akár életet veszélyeztető betegség miatt szédül. A potenciálisan veszélyes állapotot meg kell különböztetnünk a jóindulatú, veszélytelen okoktól. Nehezíti a dolgunkat, hogy a neurológiai gócjelek néha nagyon rejtettek, de veszélyes okokra mutathatnak, ezért keresnünk kell őket (Deadly D's). A páciensek kivizsgálása a részletes anamnézisfelvételen alapszik. Fontos, hogy észleljük a kísérő tüneteket. Hirtelen, súlyos, folyamatos fejfájás, aránytalanul súlyos hányás, járásképtelenség hátterében gyakran hátsó scalai stroke állhat. Tudnunk kell, hogy minden vertigo, függetlenül attól, hogy perifériás vagy centrális, fokozódik a fejmozgatásra. A szédülés időtartama és a tünetek visszatérése szignifikáns jelentőséggel bír. A 24 órán túl tartó szédüléses panaszok (AVS) segítenek kizárni az átmeneti szédüléses szindrómákat. Az AVS-t leggyakrabban vestibularis neuritis vagy agytörzsi, illetve kisagyi stroke okozza. A diagnosztikai folyamat első lépcsője a részletes anamnézisfelvétel, hangsúlyozottan rákérdezve a szédülés időtartamára, a prodromalis tünetek, kísérő tünetek, illetve rizikófaktorok jelenlétére. A neurológiai vizsgálatnak fókuszálnia kell az agytörzsi és a kisagyi góctünetekre, az önálló, segítség nélküli állás képességére és a szemmozgás zavaraira. Amennyiben elérhető, képalkotó eljárásnak a diffúziósúlyozott koponya-MRI elvégzése javasolt, mivel a natív koponya-CT szenzitivitása hátsó scalai stroke-ban alacsony. Többszöri TIA okozta szédülés az anamnézisben stroke-ra gyanús friss AVS esetén. Fájdalom és a közelmúltban lezajlott trauma arteria vertebralis dissectióra gyanús, különösen fiataloknál. Az ischaemiás stroke-ban szenvedő páciensek több mint felénél hiányoznak a szembeszökő neurológiai gócjelek, és a tüneteik jóindulatú perifériás vestibularis kórképeket utánozhatnak (pseudoneuritis). Az oculomotoros rendszer ágy melletti vizsgálata - HINTS - megbízhatóan fedezi fel a stroke-ot. Bár az audiológiai jelek gyakran perifériás eredetre utalnak, az AICA-területi stroke okozhat halláscsökkenést. Ezért az utóbbi évek kutatásai alapján a hallásvizsgálatot is szükségesnek tartják a szédülést okozó hátsó scalai stroke biztos identifikálására (HINTS plusz). A vizsgálat szenzitivitása 100\%-os a stroke-ra vonatkoztatva, jobb, mint a diffúziósúlyozott koponya-MRI szenzitivitása az első 48 órán belül és jobb, mint a hagyományos ABCD2 vizsgálaté. Speciális szemüveg használata a HINTS regisztrációját szubjektív elemektől mentessé, reprodukálhatóvá, ellenőrizhetővé teszi. Gyakorlati szempontból megfontolandó lenne az INFARCT és a NE PISZMOGJ! feliratú útmutatókat az SBO-kon elhelyezni, amelyek használata megkönnyítheti az orvosok diagnosztikai munkáját. A felesleges vizsgálatok mellőzésével egyrészt elkerülhető sok iatrogén ártalom, másrészt költség takarítható meg. Izolált szédülést okozó stroke esetén a gyors vizsgálattal idő spórolható meg („time is brain”). A betegek szoros klinikai monitorizálása alapvető jelentőségú. Az agytörzsi vagy cerebellaris stroke-ra gyanús betegeket speciális stroke-centrumokban kell kezelni. Jóindulatú AVS esetén a tüneteket rövid ideig tartó szedatív és tartósan alkalmazott szupportív kezeléssel, illetve mihamarabb megkezdett vestibularis tornával enyhítjük a betegek megfelelő edukációja, tájékoztatása mellett.

Anyagi támogatás: A kézirat Open Access megjelenését a Danavox támogatja.

Szerzői munkamegosztás: T. T. L.: Irodalomkutatás, a kézirat megszövegezése és ellenőrzése, táblázatok készítése. G. T., T. T.: A kézirat megszövegezése és ellenőrzése. Sz. Á.: Irodalomkutatás, a kézirat megszövegezése és ellenőrzése. A cikk végleges változatát valamennyi szerző elolvasta és jóváhagyta.

Érdekeltségek: Jelen kézirat témaköre dr. Tamás T. László PhD kutatási témájához kapcsolódik. 


\section{Köszönetnyilvánítás}

A szerzők köszönetüket fejezik ki Büki Béla tanár úrnak az új, ágy melletti szédülésdiagnosztikai tesztek bemutatásáért és a speciális szemüveg használatának oktatásáért.

\section{Irodalom}

[1] Collard, M., Chevalier, Y.: Vertigo. Curr. Opin. Neurol., 1994, $7(1), 88-92$.

[2] Varga, Cs., Nagy, F., Drubits, K., et al.: Analysis of patients applying for emergency treatment with vertigo related symptoms. [A sürgősségi ellátásban szédüléssel jelentkező betegek adatainak elemzése.] Ideggyogy. Sz., 2014, 67(5-6), 193-200. [Hungarian]

[3] Komoly, S., Nagy, F., Mike, A., et al.: Symptoms of dizziness. In: Programs and selected abstracts of the accredited postgraduate courses organized by the Somogy County Kaposi Mór Teaching Hospital, 2012. [A szédülések tünettana. In: A Somogy Megyei Kaposi Mór Oktató Kórház által szervezett akkreditált továbbképzések programjai és válogatott összefoglalói, 2012.] Somogy Megyei Kaposi Mór Oktató Kórház, Kaposvár, 2012. [Hungarian]

[4] Newman-Toker, D. E., Hsieh, Y. H., Camargo, C. A. Jr., et al.: Spectrum of dizziness visits to US emergency departments: cross-sectional analysis from a nationally representative sample. Mayo Clin. Proc., 2008, 83(7), 765-775.

[5] Hain, T. C.: Epidemiology of dizziness. http://www.dizzinessand-balance.com/disorders/dizzy_epi_html

[6] Eagles, D., Stiell, I. G., Clement, C. M., et al.: International survey of emergency physicians' priorities for clinical decision rules. Acad. Emerg. Med., 2008, 15(2),177-182.

[7] Szirmai, Á.: How much does an otoneurological exemination important? Analysis of patient applying for private otoneurological consultation. [Mennyire fontos az otoneurológiai vizsgálat? Egy otoneurológiai magánrendelés egy éves beteganyagának elemzése.] 42nd National Congress of the Hungarian Society of Oto-Rhino-Laryngology, Head \& Neck Surgery [MFOE 42. Nemzeti Kongresszusa], Pécs, 2012. [Hungarian]

[8] Bárány, R.: The physiology and pathology (functional) of the semicircular canals in human. [Physiologie und pathologie (funktions-prüfung) des bogengang-apparates beim menschen.] F. Deuticke, Leipzig, 1907.

[9] Szirmai, Á.: Dizziness in daily routine. [Szédülés a mindennapi gyakorlatban]. Fül-orr-gégegyógyászat, 2011, 57(4), 201-207. [Hungarian]

[10] Büki, B., Tarnutzer, A. A.: Dizziness as emergency. In: Büki, B., Tarnutzer, A. A. (eds.): Vertigo and dizziness. Oxford University Press, Oxford, 2014.

[11] Tarnutzer, A. A., Berkowitz, A. L., Robinson, K. A., et al.: Does my dizzy patient have a stroke? A systematic review of bedside diagnosis in acute vestibular syndrome. CMAJ, 2011, 183(9), E571-E592.

[12] Havia, M., Kentala, E.: Progression of symptoms of dizziness in Ménière's disease. Arch. Otolaryngol. Head Neck Surg., 2004, 130(4), 431-435.

[13] Neubauser, H., Leopold, M., von Brevern, M., et al.: The interrelations of migraine, vertigo, and migrainous vertigo. Neurology, 2001, 56(4), 436-441.

[14] Nagy, F.: Diagnosis of dizziness. In: Gerlinger, I.: Symptom oriented otorhinolaryngology. [A szédülések diagnosztikája. In: Gerlinger, I.: Tünetorientált fül-orr-gégészet.] Medicina Könyvkiadó, Budapest, 2013. [Hungarian]
[15] Edlow, J. A., Newman-Toker, D. E., Savitz, S. I.: Diagnosis and initial management of cerebellar infarction. Lancet Neurol., 2008, 7(10), 951-964.

[16] Newman-Toker, D. E., Camargo, C. A. Jr., Hsieh, Y. H., et al.: Disconnect between charted vestibular diagnoses and emergency department management decisions: a cross-sectional analysis from a nationally representative sample. Acad. Emerg. Med., 2009, 16(10), 970-977.

[17] Savitz, S. I., Caplan, L. R., Edlow, J. A.: Pitfalls in the diagnosis of cerebellar infarction Acad. Emerg. Med., 2007, 14(1), 63-68.

[18] Newman-Toker, D. E., Kerber, K. A.: Misdiagnosing dizzy patients: common pitfalls in clinical practice. In: Newman-Toker, D. E., Kerber, K. A., Meurer, J. W., et al. (eds.): Emergency neuro-otology: diagnosis and management of acute dizziness and vertigo. Elsevier, Philadelphia, 2015.

[19] Hwang, D. Y., Silva, G. S., Furie, K. L., et al.: Comparative sensitivity of computed tomography vs. magnetic resonance imaging for detecting acute posterior fossa infarct. J. Emerg. Med., $2012,42(5), 559-565$.

[20] Lee, H.: Neuro-otological aspects of cerebellar stroke syndrome. J. Clin. Neurol., 2009, 5(2), 65-73.

[21] Grad, A., Baloh, R. W.: Vertigo of vascular origin. Clinical and electronystagmographic features in 84 cases. Arch. Neurol., $1989,46(3), 281-284$.

[22] Newman-Toker, D. E.: Diagnosing dizziness in the emergency department. PhD Thesis, Johns Hopkins University, 2007.

[23] Drachman, D. A., Hart, C. W.: An approach to the dizzy patient. Neurology, 1972, 22(4), 323-334.

[24] Newman-Toker, D. E., Cannon, L. M., Stofferahn, M. E., et al.: Imprecision in patient reports of dizziness symptom quality: a cross-sectional study conducted in an acute care setting. Mayo Clin. Proc., 2007, 82(11), 1329-1340.

[25] Newman-Toker, D. E. Dy, F., J., Stanton, V. A., et al.: How often is dizziness from primary cardiovascular disease true vertigo? A systematic review. J. Gen. Intern. Med., 2008, 23(12), 20872094.

[26] Baloh, R. W.: Dizziness: neurological emergencies. Neurol. Clin., 1998, 16(2), 305-321.

[27] Kattah, J. C., Talkad, A. V., Wang, D. Z., et al.: HINTS to diagnose stroke in the acute vestibular syndrome: three-step bedside oculomotor examination more sensitive than early MRI diffusion-weighted imaging. Stroke, 2009, 40(11), 3504-3510.

[28] Halmagyi, G. M., Curthoys, I. S.: A clinical sign of canal paresis. Arch. Neurol., 1988, 45(7), 737-739.

[29] Brandt, T., Dieterich, M., Strupp, M.: Introductory remarks. In: Brandt, T., Dieterich, M., Strupp, M. (eds.): Vertigo and dizziness. Springer Verlag, London, 2013.

[30] Brodsky, M. C., Donahue, S. P., Vaphiades, M., et al.: Skew deviation revisited. Surv. Ophthalmol., 2006, 51(2), 105-128.

[31] Newman-Toker, D. E., Kerber, K. A., Hsieh, Y. H., et al.: HINTS outperforms $\mathrm{ABCD} 2$ to screen for stroke in acute continuous vertigo and dizziness. Acad. Emerg. Med., 2013, 20(10), 986996.

[32] Weber, K. P., Aw, S. T., Todd, M. J., et al.: Head impulse test in unilateral vestibular loss: vestibulo-ocular reflex and catch-up saccades. Neurology, 2008, 70(6), 454-463.

[33] Mantokoudis, G., Tehrani, A. S., Wozniak, A., et al.: VOR gain by head impulse video-oculography differentiates acute vestibular neuritis from stroke. Otol. Neurotol., 2015, 36(3), 457-465.

(Tamás T. László dr., Györ, Vak Bottyán u. 14/A, 9028 e-mail: ltamas@gyor.net) 